\title{
26. PALEOLATITUDE INFERRED FROM CRETACEOUS SEDIMENTS, HOLE 865A, ALLISON GUYOT, MID-PACIFIC MOUNTAINS ${ }^{1}$
}

\author{
William W. Sager ${ }^{2}$ and John A. Tarduno ${ }^{3}$
}

\begin{abstract}
We measured the paleomagnetism of 53 limestone samples recovered from Hole 865A, atop Allison Guyot in the Mid-Pacific Mountains, to place constraints on the paleolatitude of the edifice near the time of its formation. Most samples were recovered from the bottom of the hole, in a section of Albian (probable early Albian) clayey limestone deposited in a marshy, nearshore environment and intruded by several basaltic sills while soft. Natural remanent magnetization (NRM) intensities displayed a large range, varying by more than five orders of magnitude and generally decreasing upsection. The NRM intensities probably reflect the concentration of volcanic grains, eroded from a nearby volcanic high and deposited in the sediments. Saturation of isothermal remanent magnetizations in low applied fields and moderate mean destructive field values are consistent with titanomagnetite as the dominant magnetic grain type in these limestones. Nearly all samples showed stable behavior during alternating field (AF) demagnetization and gave apparently reliable characteristic remanence directions. A mean inclination of $-26.8^{\circ}(95 \%$ confidence limits: $-24.4^{\circ},-28.7^{\circ} ; k=75 ; N=51$ ) implies a paleolatitude of $14.2^{\circ} \pm 1.3^{\circ} \mathrm{S}$. This value is statistically indistinguishable from that inferred from the mid-Cretaceous Pacific apparent polar wander path (APWP), suggesting that the paleolatitude is reliable.
\end{abstract}

\section{INTRODUCTION}

The Pacific Plate is almost entirely covered by water; thus, tracking its past motions and paleolatitudes is challenging because oriented paleomagnetic samples are difficult to recover from the deep sea. Samples of Cretaceous formations are especially hard to obtain, as they are typically found deep in the ocean, often covered by younger sediments. Thus, when mid-Cretaceous sediments and basalts were cored from Allison Guyot during Ocean Drilling Program (ODP) Leg 143 , it allowed us the opportunity to add to the meager subset of Pacific paleomagnetic data of that age.

Hole $865 \mathrm{~A}\left(18.44^{\circ} \mathrm{N}, 180.44^{\circ} \mathrm{E}\right)$ was drilled into the center of Allison Guyot, located in the west-central Pacific Ocean within the Mid-Pacific Mountains province (Sager, Winterer, Firth, et al., 1993). The hole penetrated approximately $871 \mathrm{~m}$ into the summit, passing through $136 \mathrm{~m}$ of Cenozoic pelagic sediments; $702 \mathrm{~m}$ of Cretaceous lagoonal-facies, shallow-water platform limestones; and $33 \mathrm{~m}$ of interfingered platform limestones and basalt sills. Geochemical similarities suggest that the sills were intruded as a single event. Furthermore, the disturbance of surrounding sediments implies that they were unconsolidated during the intrusion; therefore, the sills are apparently contemporaneous with the host sediments (Sager, Winterer, Firth, et al., 1993).

Biostratigraphy (Vanneau and Sliter, this volume) and Sr-isotope data (Jenkyns et al., this volume) suggest that the shallow-water limestone section spans much of the Albian stage (97-112 Ma, by the time scale of Harland et al., 1990). The base of the limestones is probably lower Albian, whereas the top of the limestones is upper Albian (Vanneau and Sliter, this volume). These ages agree with ${ }^{40} \mathrm{Ar}-{ }^{39} \mathrm{Ar}$ radiometric dates from the drilled basalts (104.8 \pm 0.8 , $111.2 \pm 1.2 \mathrm{Ma}$; Pringle, this volume), as well as basalts dredged from the guyot flanks (101.2 $\pm 0.8 \mathrm{Ma}$; Winterer et al., 1993).

The Cretaceous shallow-water lithologic succession of Hole $865 \mathrm{~A}$ seems to show the evolution of the edifice from a volcanic island to

\footnotetext{
' Winterer, E.L., Sager, W.W., Firth, J.V., and Sinton, J.M. (Eds.), 1995. Proc. ODP, Sci. Results, 143: College Station, TX (Ocean Drilling Program).

${ }^{2}$ Departments of Oceanography and Geophysics, Texas A\&M University, College Station, TX 77843, U.S.A

${ }^{3}$ Department of Earth and Environmental Sciences, University of Rochester, Rochester, NY 14627, U.S.A.
}

an open-marine atoll (Sager, Winterer, Firth, et al., 1993). The deepest $133 \mathrm{~m}$ of Cretaceous limestones contains abundant organic matter and appears to have been deposited along the shoreline in the restricted, stagnant waters of a swamp. Pyrite is present, implying reduction, but pervasive bioturbation throughout most of this section indicates that the waters contained sufficient oxygen for shallow infaunal activity. Abundant clay and volcanic grains that occur in these limestones are probably the product of erosion from nearby volcanic outcrops. Progressing upward through the section, the Cretaceous limestones become progressively "cleaner," with less clay and organic matter. Evidently, the shoreline retreated from the site and the volcanic outcrops were buried as the edifice evolved into an atoll or shallow-water carbonate platform.

\section{METHODS}

Fifty-three paleomagnetic samples were taken from Hole $865 \mathrm{~A}$ cores as 10 to $12 \mathrm{~cm}^{3}$ minicores, $2.5 \mathrm{~cm}$ in diameter and typically 2.0 to $2.5 \mathrm{~cm}$ in length. All but two are from 748 to $866 \mathrm{mbsf}$ (Table 1), within the clay-rich limestones near the bottom of the hole. The minicores were drilled perpendicular to the split face of the core (a vertical plane) and were oriented with a mark to indicate the upward direction.

To obtain an indication of variations of magnetic grain concentration, volume magnetic susceptibility was measured for each sample using a Bartington MS-2 susceptibility meter having a 36-mm sensing loop. This device has a sensitivity of $10^{-6} \mathrm{SI}$. Sample remanences were measured with a cryogenic magnetometer having an effective sensitivity limit of approximately $0.005 \mathrm{~mA} / \mathrm{m}$. A subset of samples first was treated to detailed, stepwise alternating field (AF) demagnetization (16-18 steps) and then remagnetized with an isothermal remanent magnetization (IRM) in fields up to $1200 \mathrm{mT}$ using a pulsemagnetizer. These pilot experiments suggested the efficacy of using AF demagnetization on Hole $865 \mathrm{~A}$ samples; thus, in the remainder, characteristic remanent magnetization (ChRM) directions were isolated using $\mathrm{AF}$ demagnetization, typically with 8 to 12 steps in fields up to 60 to $80 \mathrm{mT}$.

Orthogonal-vector and stereonet plots were made of vector endpoints of all demagnetization steps of all samples. These plots allowed us to determine which steps defined a ChRM by univectorial decay. To calculate the ChRM direction, we used a linear least-squares line fit to the univectorial segment directions (Kirschvink, 1980), typically with the solution anchored to the origin. 
Table 1. Paleomagnetic data, Hole 865A limestone samples.

\begin{tabular}{|c|c|c|c|c|c|c|c|c|c|}
\hline $\begin{array}{l}\text { Core, section, } \\
\text { interval }(\mathrm{cm})\end{array}$ & $\begin{array}{l}\text { Depth } \\
\text { (mbsf) }\end{array}$ & $\begin{array}{c}\text { Inc } \\
\text { (deg.) }\end{array}$ & $\begin{array}{l}\text { MAD } \\
\text { (deg.) }\end{array}$ & $N$ & $\begin{array}{l}\text { AF } \\
\text { steps }\end{array}$ & $\begin{array}{c}J_{\mathrm{o}} \\
(\mathrm{mA} / \mathrm{m})\end{array}$ & $J / J_{\mathrm{s}}$ & $\begin{array}{l}\text { MDF } \\
(\mathrm{mT})\end{array}$ & $\begin{array}{c}\text { Susc. } \\
\left(\text { SI } \times 10^{-5}\right)\end{array}$ \\
\hline \multicolumn{10}{|l|}{ 143-865A- } \\
\hline $34 \mathrm{R}-1,37-39$ & 294.57 & $30.4^{a}$ & 3.8 & 9 & $10-70$ & 0.049 & 0.76 & 70 & -0.8 \\
\hline $74 \mathrm{R}-1.43-45$ & 680.13 & -37.1 & 3.6 & 5 & $10-30$ & 0.083 & 0.39 & 25 & -0.9 \\
\hline $81 R-1,98-100$ & 748.38 & -26.6 & 12.5 & 4 & $30-45$ & 0.107 & 0.18 & 20 & -0.3 \\
\hline $82 \mathrm{R}-2,7-9$ & 758.12 & -18.1 & 6.5 & 6 & $5-20$ & 0.095 & 0.39 & 2 & -0.1 \\
\hline $82 R-2,22-24$ & 758.27 & Not stable & & & & 0.104 & & 3 & -0.6 \\
\hline $84 \mathrm{R}-1.61-63$ & 777.11 & Not stable & & & & 0.018 & & 9 & -0.5 \\
\hline $84 \mathrm{R}-1.90-92$ & 777.40 & -25.3 & 6.5 & 4 & $7-15$ & 0.028 & 0.32 & 12 & -0.3 \\
\hline $85 \mathrm{R}-1.38-40$ & 786.58 & $29.8^{\mathrm{at}}$ & 2.8 & 9 & $10-50$ & 0.294 & 0.18 & 10 & -0.1 \\
\hline $85 R-1,65-67$ & 786.85 & -27.0 & 2.4 & 7 & $10-40$ & 0.245 & 0.32 & 12 & 0.1 \\
\hline $85 R-2.49-51$ & 787.92 & -33.4 & 1.3 & 10 & $10-60$ & 0.415 & 0.18 & 19 & 0.9 \\
\hline $86 \mathrm{R}-\mathrm{I} .127-129$ & 797.07 & -27.8 & 2.9 & 8 & $20-60$ & 0.270 & 0.28 & 20 & 0.3 \\
\hline $86 \mathrm{R}-1,143-145$ & 797.23 & -20.0 & 1.3 & 9 & $10-50$ & 0.567 & 0.19 & 11 & 0.7 \\
\hline $86 R-2,77-79$ & 798.07 & -29.2 & 1.7 & 9 & $10-60$ & 0.643 & 0.27 & 22 & 0.7 \\
\hline $86 \mathrm{R}-2,107-109$ & 798.37 & -25.2 & 0.8 & 7 & $10-50$ & 1.201 & 0.16 & 8 & 1.1 \\
\hline $86 \mathrm{R}-2,141-143$ & 798.71 & -28.5 & 1.8 & 7 & $20-60$ & 0.607 & 0.18 & 12 & 0.7 \\
\hline $87 \mathrm{R}-1,40-42$ & 805.80 & -32.4 & 2.5 & 10 & $10-70$ & 0.425 & 0.17 & 13 & 0.1 \\
\hline $87 R-1.44-46$ & 805.84 & -25.8 & 4.3 & 8 & $15-60$ & 0.231 & 0.17 & 14 & 0.3 \\
\hline $87 \mathrm{R}-1,83-85$ & 806.23 & -27.3 & 1.9 & 7 & $10-50$ & 0.502 & 0.14 & 8 & 0.1 \\
\hline $87 R-2,11-13$ & 806.88 & -32.1 & 1.9 & 8 & $15-70$ & 0.479 & 0.18 & 15 & 0.5 \\
\hline $88 \mathrm{R}-1,13-15$ & 815.23 & -28.9 & 1.2 & 7 & $15-60$ & 1.306 & 0.12 & 9 & 1.3 \\
\hline $88 \mathrm{R}-1,91-93$ & 816.01 & -31.7 & 1.1 & 7 & $10-40$ & 0.544 & 0.18 & 10 & 0.6 \\
\hline $88 \mathrm{R}-2.40-42$ & 816.95 & -29.0 & 2.7 & 7 & $20-70$ & 8.032 & 0.29 & 11 & 16.7 \\
\hline $89 \mathrm{R}-1,17-19$ & 824.97 & -24.5 & 4.9 & 5 & $15-40$ & 136.060 & 0.05 & 4 & 371.6 \\
\hline $89 \mathrm{R}-1.85-87$ & 825.65 & -21.9 & 3.1 & 6 & $10-40$ & 145.840 & 0.10 & 12 & 709.9 \\
\hline $89 \mathrm{R}-1.111-113$ & 825.91 & -19.4 & 3.4 & 9 & $15-60$ & 246.780 & 0.04 & 11 & 100.9 \\
\hline $89 \mathrm{R}-1,119-121$ & 825.99 & -24.5 & 1.6 & 9 & $12-50$ & 178.640 & 0.04 & 13 & 892.2 \\
\hline $89 R-2,15-17$ & 826.32 & -35.8 & 5.3 & 5 & $20-50$ & 193.280 & 0.09 & 13 & 1061 \\
\hline $89 \mathrm{R}-2,96-98$ & 827.12 & -27.4 & 4.6 & 5 & $10-30$ & 136.790 & 0.18 & 17 & 1003.6 \\
\hline $89 \mathrm{R}-2,121-123$ & 827.38 & -44.4 & 3.7 & 6 & $15-50$ & 131.510 & 0.08 & 17 & 1013.5 \\
\hline $89 R-3,11-13$ & 827.66 & -15.4 & 4.2 & 5 & $20-40$ & 441.120 & 0.03 & 4 & 694.1 \\
\hline $89 R-3,76-78$ & 828.31 & -20.2 & 3.6 & 7 & $10-50$ & 273.330 & 0.03 & 5 & 851.5 \\
\hline $89 R-4,16-18$ & 829.07 & -29.1 & 2.0 & 5 & $20-50$ & 174.380 & 0.04 & 7 & 512.3 \\
\hline $89 \mathrm{R}-4,40-42$ & 829.31 & -31.1 & 2.3 & 6 & $10-40$ & 197.880 & 0.08 & 7 & 913 \\
\hline $89 \mathrm{R}-6,36-38$ & 831.69 & -29.7 & 3.5 & 8 & $20-70$ & 0.844 & 0.30 & 30 & 2.5 \\
\hline $89 R-6,43-45$ & 831.76 & -12.9 & 2.3 & 8 & $5-60$ & 0.771 & 0.55 & 50 & 2.8 \\
\hline $90 \mathrm{R}-1,21-23$ & 832.01 & -18.1 & 4.7 & 6 & $25-70$ & 1.279 & 0.26 & 25 & 1.6 \\
\hline $90 \mathrm{R}-\mathrm{I}, 3 \mathrm{I}-33$ & 832.11 & -23.5 & 2.7 & 5 & $25-60$ & 1.556 & 0.29 & 27 & 2 \\
\hline $90 \mathrm{R}-1,58-60$ & 832.38 & -23.1 & 1.9 & 6 & $25-70$ & 1.248 & 0.12 & 10 & 1.7 \\
\hline $90 \mathrm{R}-1.71-73$ & 832.51 & -28.1 & 2.4 & 7 & $15-50$ & 0.679 & 0.14 & 12 & 1.7 \\
\hline $90 \mathrm{R}-2,13-15$ & 833.07 & -240 & 10 & 9 & $20-80$ & 1.708 & 0.09 & 13 & 2.8 \\
\hline $90 \mathrm{R}-2,55-56$ & 833.49 & -26.1 & 1.0 & 7 & $15-60$ & 1.450 & 0.21 & 20 & 4.3 \\
\hline $90 R-2,115-117$ & 834.09 & -29.0 & 16 & 7 & $25-60$ & 1.587 & 0.19 & 20 & 3.4 \\
\hline $90 \mathrm{R}-3,2-4$ & 834.23 & -37.8 & 2.1 & 10 & $15-70$ & 2.006 & 0.14 & 18 & 2.7 \\
\hline $90 \mathrm{R}-3.63-65$ & 834.84 & -21.8 & 1.7 & 8 & $15-50$ & 0.381 & 0.20 & 12 & 1.2 \\
\hline $9 \mid \mathrm{R}-3,78-80$ & 844.57 & -5.5 & 5.1 & 7 & $20-50$ & 5.625 & 0.22 & 19 & 42.3 \\
\hline $91 \mathrm{R}-4,4-6$ & 845.33 & -22.8 & 1.9 & 9 & $10-70$ & 4.696 & 0.20 & 20 & 7.9 \\
\hline $9 \mid R-4,35-37$ & 845.64 & -291 & 13 & 11 & $10-80$ & 2.318 & 0.21 & 28 & 3.4 \\
\hline $91 \mathrm{R}-5,123-125$ & 847.89 & -30.0 & 4.4 & 7 & $30-70$ & 0.972 & 0.15 & 18 & 3 \\
\hline $92 \mathrm{R}-1,33-35$ & 847.53 & -27.6 & 1.5 & 10 & $20-80$ & 0.605 & 0.16 & 19 & 1.1 \\
\hline $92 \mathrm{R}-1,82-84$ & 848.02 & -36.4 & 1.8 & 9 & $25-80$ & 7.398 & 0.06 & 4 & 4.4 \\
\hline $92 \mathrm{R}-2,2-4$ & 848.58 & -28.1 & 1.2 & 10 & $20-80$ & 3.312 & 0.20 & 15 & 92.3 \\
\hline $94 \mathrm{R}-3,10-12$ & 865.97 & -217 & 3.8 & 9 & $20-70$ & 15.340 & 0.09 & 18 & 59.2 \\
\hline $94 \mathrm{R}-3,26-28$ & 866.13 & -19.9 & 3.1 & 6 & $35-80$ & 7.205 & 0.14 & 17 & 22.7 \\
\hline
\end{tabular}

Notes; Inc = inclination of characteristic remanence, determined by least-squares line fit; $\mathrm{MAD}=$ maximum angle of deflection (Kirschvink, 1980 ); $N=$ number of steps used for calculating least-squares line: $\mathrm{AF}$ steps $=$ range of alternating fields for steps used in line fit calculation; $J_{0}=$ intensity of natural remanent magnetization, in milliamperes per meter: $J / J_{0}=$ percentage of $J_{0}$ remaining at highest AF demagnetization step used in line fit calculation; MDF $=$ median destructive field, AF demagnetization field at which $50 \%$ of $J_{0}$ remained. Susc, = volume magnetic susceptibility. ${ }^{\text {aS }}$ ample inverted.

Because the cores were drilled with a rotary bit, core fragments were twisted off from the country rock as they were drilled and, thus, are azimuthally unoriented. Sample paleomagnetic declinations, therefore, are arbitrary, and only the paleomagnetic inclinations have geologic significance. To calculate mean paleoinclinations, we must correct for the bias inherent when averaging inclination-only data (Briden and Ward, 1966; Cox and Gordon, 1984). Consequently, we used a maximum-likelihood routine designed to calculate corrected mean inclination values and their confidence limits (McFadden and Reid, 1982).

\section{RESULTS}

Samples were restricted to the base of the limestone section because recovery was low in much of the hole (typically $<5 \%$ ) and did not exceed $20 \%$, except in the lower $100 \mathrm{~m}$. Recovery increased dramatically in the clayey limestones in this part of the hole and is approximately correlated with the intensity of magnetization of the samples, probably because the clays and volcanic detritus made the limestones both less friable and more magnetic.

Natural remanent magnetization (NRM) intensities of the limestone samples ranged over five orders of magnitude, from 0.049 to $441.120 \mathrm{~mA} / \mathrm{m}$, and magnetic susceptibility ranged by a similar amount, from $-0.9 \times 10^{-5}$ to $1061.0 \times 10^{-5}$ SI (Table 1; Appendix). NRM intensity correlates well with susceptibility, implying that magnetic mineral concentration is the primary factor controlling its magnitude (Fig. 1). NRM intensities of samples above Core 143-865A-85R (786.2 mbsf) were the weakest. Indeed, these samples were difficult to measure with the cryogenic magnetometer, owing to their low magnetizations. Intensities of other samples were typically between 0.2 to $15.0 \mathrm{~mA} / \mathrm{m}$, except for a zone of highly magnetic limestones in Sections $143-865 \mathrm{~A}-89 \mathrm{R}-1$ to -4 ( 824.7 to $830.4 \mathrm{mbsf})$, which gave values from 136.060 to $441.120 \mathrm{~mA} / \mathrm{m}$ (Table 1). Magnetic intensity also correlates with color, with weaker limestones being whiter and stronger limestones being darker greenish-black. The color changes probably reflect differences in the amount of volcanic material in the sediments, 


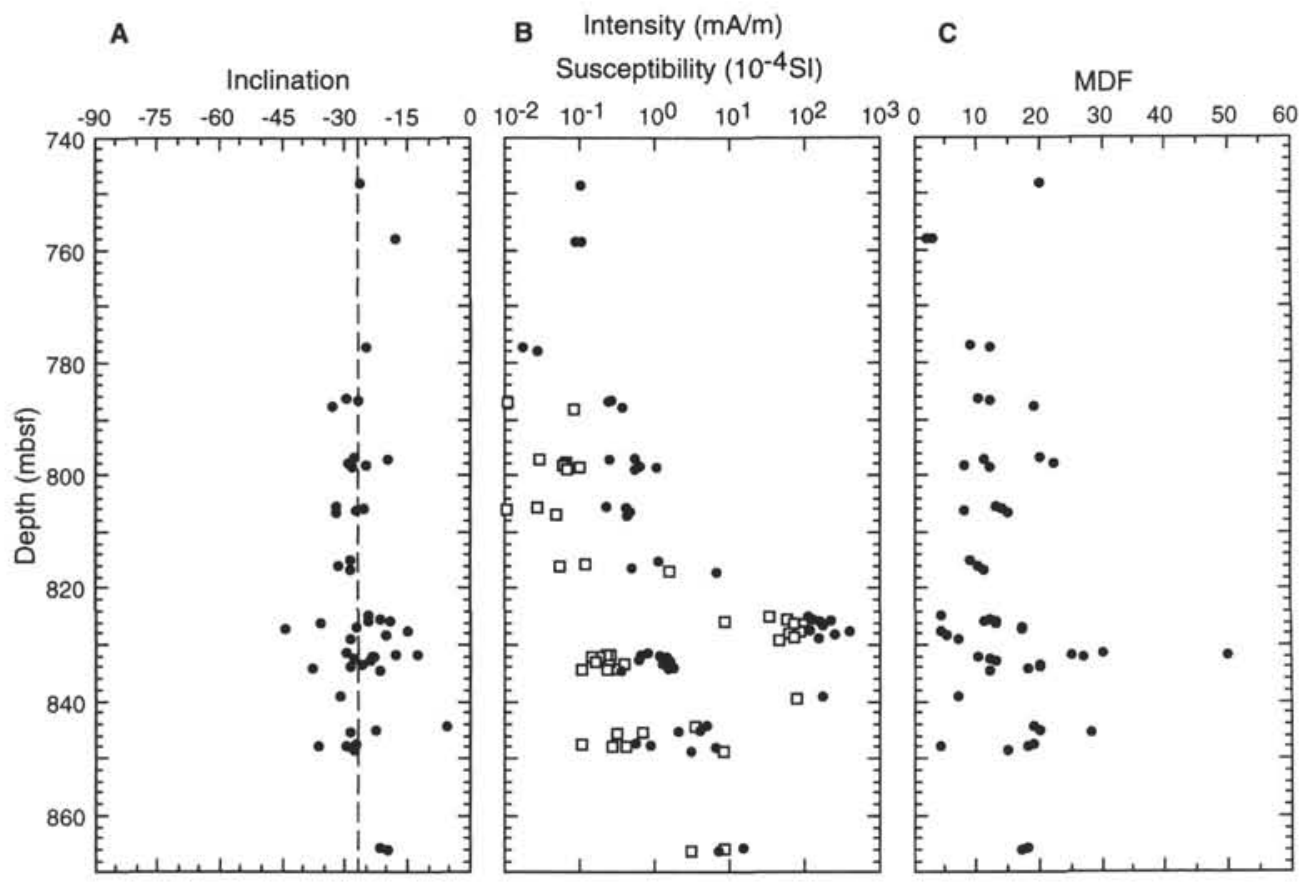

Figure 1. Magnetization properties of Cretaceous limestone samples. A. Paleoinclination of the characteristic remanent magnetization vs. depth. Dashed line shows the average inclination. B. Natural remanent magnetization (NRM) intensity (solid circles) and volume magnetic susceptibility (open squares) plotted vs. depth; intensity units in $\mathrm{mA} / \mathrm{m}$; susceptibility in $10^{-4} \mathrm{SI}$. Note that the horizontal scale is logarithmic. C. Median destructive field (MDF) values plotted vs. depth. MDF in milliteslas.
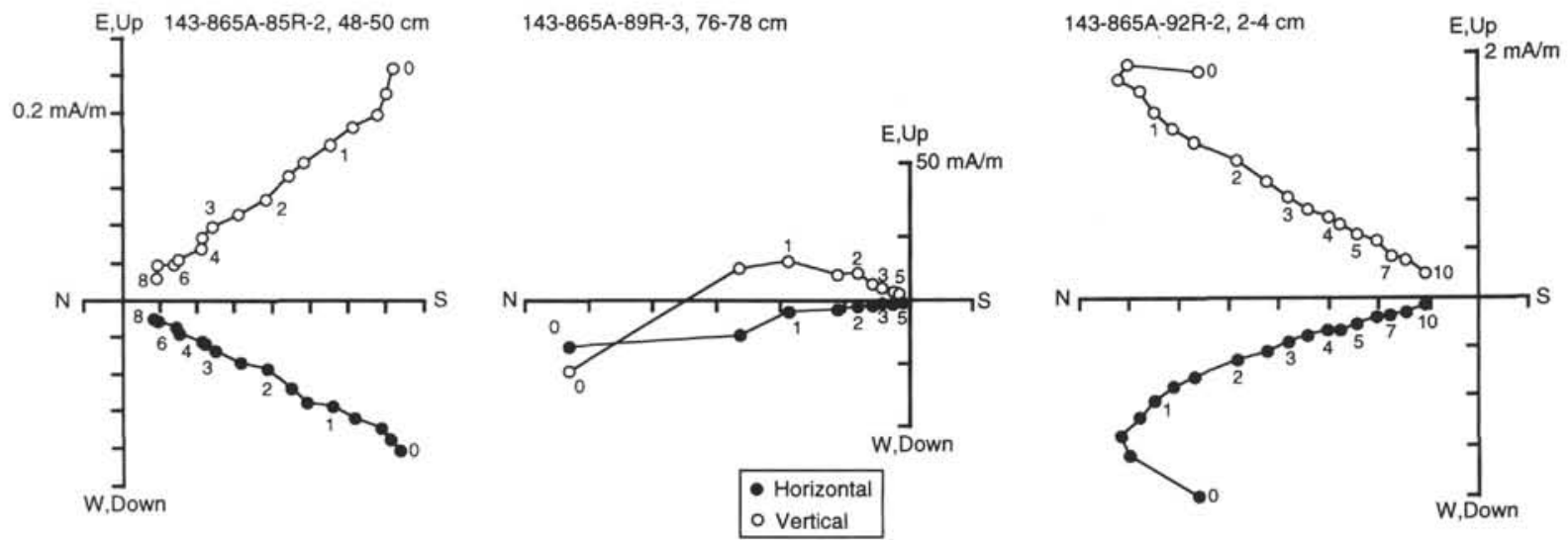

Figure 2. Orthogonal vector ("Zijderveld") plots of the behavior of three typical Cretaceous limestone samples during AF demagnetization. Numbers indicate AF demagnetization steps, in tens of milliteslas.

but may also be related to changes in the environment of deposition and, hence, diagenesis, owing to other factors, such as the influx of organic material.

Most samples exhibited stable AF demagnetization behavior: little scatter in direction and univectorial decay toward the origin (Fig. 2). The only samples that displayed unstable behavior were weakly magnetic samples of "clean" limestone in the sections above Core 143-865A-85R (786.2 mbsf). AF demagnetization was effective in removing overprint magnetizations and isolating sample ChRMs (Fig. 2). Many samples showed no significant overprint; those that did, exhibited no consistent overprint direction. This suggests that the overprints were acquired from the environment during handling.

IRM acquisition experiments showed that most pilot samples saturated in applied fields of $400 \mathrm{mT}$ or less (Fig. 3), implying that their magnetizations reside in a low-coercivity magnetic mineral, such as titanomagnetite. Low median destructive field (MDF) values,
$25 \mathrm{mT}$ or less, characterize most samples (Fig. 1), suggesting that this behavior is the norm. However, a few samples displayed higher coercivities, as shown by larger applied fields needed to bring them to saturation (Fig. 2) and higher MDF values. Only five of 53 samples (9\%) had MDF values in excess of $25 \mathrm{mT}$ (Fig. 1). These samples did not give paleoinclination values any different than the other samples; thus, AF demagnetization was evidently able to isolate the ChRM in the higher coercivity samples as well.

All but two samples gave negative ChRM inclinations (Table 1), indicating that the limestones were magnetized in the Southern Hemisphere during a period of normal geomagnetic polarity. This is consistent with their having acquired their magnetizations during the Albian stage, in the middle of the Cretaceous Quiet Period. The two samples with positive inclinations (143-865A-34R-1, 37-39 cm, and $-85 \mathrm{R}-1,38-40 \mathrm{~cm}$ ) probably do not indicate reversed polarity, but were likely inverted during handling. Neither exhibits a demagneti- 


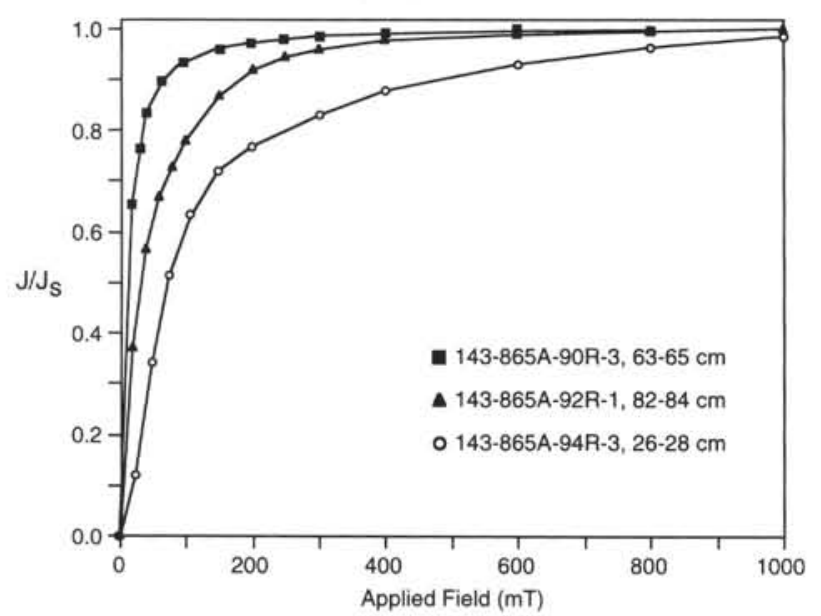

Figure 3. IRM acquisition curves for three Cretaceous limestone samples. On the vertical axis is magnetic intensity normalized by the saturation value; on the horizontal axis, the applied field in milliteslas. Most samples show low coercivity behavior, as the upper two curves, with saturation occurring in fields of $200-400 \mathrm{mT}$; however, a small percentage of samples show a high coercivity behavior, evidenced by saturation occurring in higher applied fields, as in the lower curve.

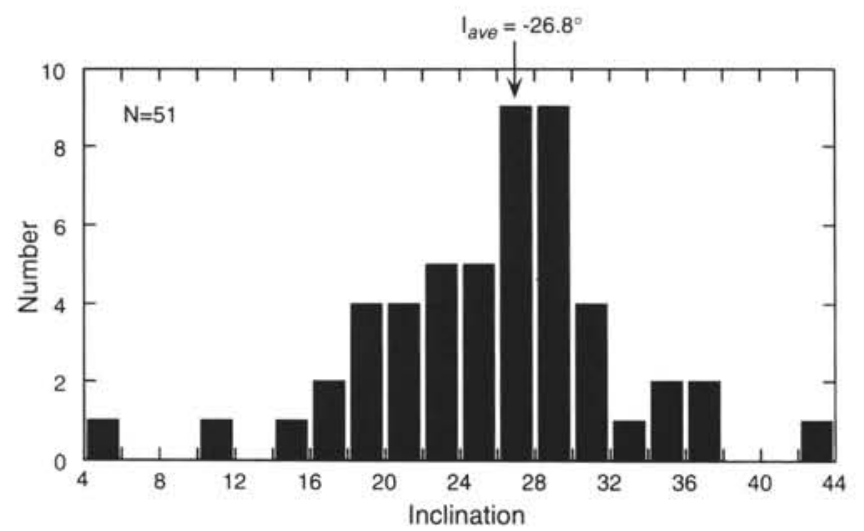

Figure 4. Histogram of characteristic remanent magnetization inclinations for Hole 865A clayey limestone samples.

zation behavior that would suggest a reversed polarity ChRM overprinted with a normal polarity (Brunhes or Cretaceous Quiet Period) magnetization, as is common for similar, reversely magnetized deepsea sediments (e.g., Steiner, 1983).

Paleoinclination values display remarkably low scatter (Fig. 4) and although the inclination histogram appears somewhat biased toward shallow values, the distribution has a skewness value near zero (0.06), indicating that it is indistinguishable from a normal distribution. The grouping implies that these samples recorded the same paleofield direction, which has been reliably isolated. A mean inclination of $-26.8^{\circ}$ ( $95 \%$ confidence limits: $-24.4^{\circ}$ to $-28.7^{\circ} ; k=$ $75 ; N=51$ ) was calculated. Thus, the limestones imply a paleolatitude of $14.2^{\circ} \mathrm{S}$ with $95 \%$ confidence limits of approximately $\pm 1.3^{\circ}$.

\section{DISCUSSION}

The $-14.2^{\circ} \pm 1.3^{\circ}$ paleolatitude estimated from the sediments is indistinguishable from that given by the basalts from the same unit $\left(-16.8^{\circ} \pm 3.0^{\circ}\right.$; Sager, Winterer, Firth, et al., 1993). This paleolatitude implies that Site 865 has drifted $32.6^{\circ}$ northward since the limestones were deposited, an amount similar to estimates for Leg 129 sites

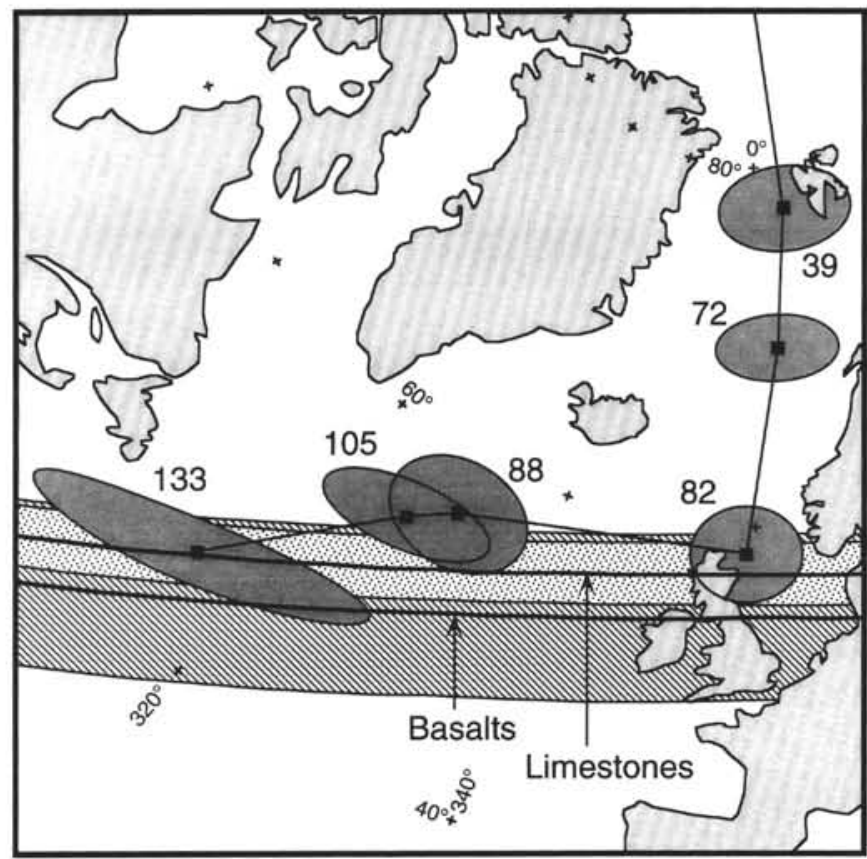

Figure 5. Comparison of paleocolatitudes from Hole 865A clayey-limestone samples and basalt sills (Sager, Winterer, Firth, et al., 1993) with the Pacific apparent polar wander path. The polar wander path is shown by solid squares connected by a line. Each pole is identified by its mean age (in Ma) and is surrounded by its $95 \%$ confidence ellipse (from Sager and Pringle, 1988; Larson and Sager, 1992; Sager, unpubl. data). Heavy, nearly horizontal arcs show the locus of paleomagnetic poles inferred from azimuthally unoriented Hole $865 \mathrm{~A}$ mean paleoinclinations (sediments and basalts). The $95 \%$ confidence limits for the basalt and limestone paleocolatitudes are shown by the cross hatched and stippled bands, respectively.

$\left(29^{\circ}-37^{\circ}\right)$ located on Jurassic lithosphere, approximately $2800 \mathrm{~km}$ west of Allison Guyot (Larson et al., 1992; Steiner and Wallick, 1992). Few mid-Cretaceous paleomagnetic data exist for the Pacific Plate; thus, some uncertainty exists in the polar wander of this period. Published APWP for that period trend more-or-less east to west (Gordon, 1983; Cox and Gordon, 1984; Sager and Pringle, 1988; Sager, 1992; Larson and Sager, 1992; Fig. 5), implying that there was little paleolatitude change for the plate during that period (e.g., Larson et al., 1992). Therefore, we need not have a paleomagnetic pole of precisely the same age for comparison. Nevertheless, we determined a pole using paleomagnetic data from seamount magnetic anomaly inversions and DSDP basalt and sediment cores (Sager, unpubl. data). The result is located at $55.0^{\circ} \mathrm{N}, 326.8^{\circ} \mathrm{E}$ and has an average age of 105 $\mathrm{Ma}$. From this pole, we infer an expected paleolatitude of $-11.2^{\circ} \pm$ $2.0^{\circ}$. The confidence limits of both the limestone and basalt paleocolatitude estimates overlap those of the $105 \mathrm{Ma}$ mean pole, implying agreement of these data (Fig. 5).

Geological observations from the cores and the low scatter of their inclinations (Sager, Winterer, Firth, et al. ,1993) are consistent with the sills having been emplaced within a short time; thus, they should record only geomagnetic field directions representative of a few years, during the period of their cooling. Secular variation studies suggest that an equatorial site should have a standard deviation of about $9^{\circ}$ (implying $95 \%$ confidence limits of approximately $18^{\circ}$ ) in paleolatitude owing to this phenomenon (Harrison, 1980; Cox and Gordon, 1984); therefore, the match of the basalt paleolatitude and the expected paleolatitude is probably fortuitous.

The agreement of the paleolatitude determined from the limestones with the expected paleolatitude is somewhat surprising, be- 
cause many cores of Cretaceous sediments from Pacific DSDP and ODP holes have been found to give anomalously shallow inclinations (Tarduno, 1990; Gordon, 1990; Steiner and Wallick, 1992). It is possible that the 105-Ma reference paleomagnetic pole is biased toward lower paleolatitudes, because it is controlled in part by data from other Cretaceous DSDP sediment cores and by paleopoles from the inversion of seamount magnetic anomalies, which can give shallow inclinations owing to viscous remanent magnetization overprint (e.g., Gee et al., 1993). Nevertheless, the sediment data used for the reference pole were those that seem to be unbiased by their concordance with other Pacific paleomagnetic data (Tarduno, 1990; Gordon, 1990). Moreover, basalt core data from a number of DSDP sites also were used in the calculation. Thus, a biased reference pole seems unlikely and the Hole $865 \mathrm{~A}$ sediment paleolatitude appears reliable.

The causes of inclination shallowing in sediments are not well understood; thus, it is difficult to pinpoint the reason why the Hole $865 \mathrm{~A}$ limestones give reliable results. One often-cited explanation for inclination shallowing is that it is caused during compaction and dewatering by the rotation of magnetic grains toward the horizontal, either by the physical rotation of elongated magnetic grains or by their becoming attached to platelike clusters of clay particles (Blow and Hamilton, 1978; Anson and Kodama, 1987). We can imagine several factors that might have mitigated compaction effects. Although the Hole $865 \mathrm{~A}$ limestones we measured had variable, but significant, amounts of clay, possibly the nearness to the source rocks prevented inclination shallowing, because the magnetic grains are larger and, thus, less likely to be affected by the clay particles. Alternatively, these carbonate sediments may have resisted compaction by rapid cementation before significant burial. For example, deeply buried carbonate sandstones were drilled at sites on Resolution Guyot that had intact void spaces caused during deposition by trapped air (Sager, Winterer, Firth, et al., 1993). Another possibility is that the heat and hot fluid flow associated with the sill intrusions may have remagnetized the sediments after much of the compaction had already occurred. Without a more thorough study of the petrography of these sediments, all of these suggestions are speculative.

\section{CONCLUSIONS}

Shallow-water limestone samples from Hole 865A displayed a wide range of NRM intensity, with a variation over more than five orders of magnitude. Higher intensities were found in the clayey limestones recovered in the $140 \mathrm{~m}$ above the bottom of the hole; these evidently resulted from the influx of volcanic material into the sediments from a nearby volcanic island. These sediments were deposited in a nearshore lagoonal marsh environment, and their magnetic properties seem to be the characteristic of titanomagnetite grains.

Biostratigraphic data give an age of Albian (probably lower Albian) for the measured limestones, whereas an average radiometric age of $104.5 \pm 0.5$ Ma was determined from the cored basalt sills and dredge material. Paleoinclination data gave a mean of $-26.8^{\circ}$ and $95 \%$ confidence limits of $-24.4^{\circ}$ to $-28.7^{\circ}$. This inclination implies a paleolatitude of $-14.2^{\circ} \pm 1.3^{\circ}$, which is indistinguishable from paleolatitudes inferred from a 105 -Ma reference pole $\left(-11.2^{\circ} \pm 2.0^{\circ}\right)$ and from basalt sills that intruded these sediments $\left(-16.8^{\circ} \pm 3.0^{\circ}\right)$. This concordance suggests that the paleomagnetic results from these limestones were not biased by compaction-induced inclination shallowing.

\section{ACKNOWLEDGMENTS}

We thank the JOI/USSAC science support program for providing funds for this study. Reviews by Charles Helsley and an anonymous reviewer were appreciated. Craig Jones, of CIRES, at the University of Colorado, Boulder, kindly provided a Macintosh program to plot and analyze sample magnetizations; his many hours of programming and debugging are greatly appreciated. This is Texas A\&M Geodynamics Research Institute Contribution No. 94.

\section{REFERENCES $*$}

Anson, G.L., and Kodama, K.P., 1987. Compaction-induced shallowing of the post-depositional remanent magnetization in a synthetic sediment. Geophys. J. R. Astron. Soc., 88:673-692.

Blow, R.A., and Hamilton, N., 1978. Effect of compaction on the acquisition of a detrital remanent magnetization in fine-grained sediments. Geophys. J. R. Astron. Soc., 52:13-23.

Briden, J.C., and Ward, M.A., 1966. Analysis of magnetic inclination in borecores. Pure Appl. Geophys. 57:47-52.

Cox, A., and Gordon, R.G., 1984. Paleolatitudes determined from paleomagnetic data from vertical cores. Rev. Geophys. Space Phys., 22:42-72.

Gee, J., Staudigel, H., Tauxe, L., and Pick, T., 1993. Magnetization of the La Palma Seamount Series: implications for seamount paleopoles. J. Geophys. Res., 98:11743-11767.

Gordon, R.G., 1983. Late Cretaceous apparent polar wander of the Pacific plate: evidence for a rapid shift of the Pacific hotspots with respect to the spin axis. Geophys. Res. Lett., 10:709-712.

1990. Test for bias in paleomagnetically determined paleolatitudes from Pacific Plate Deep Sea Drilling Project sediments. J. Geophys. Res., 95:8397-8404.

Harland, W.B., Armstrong, R.L., Cox, A.V., Craig, L.E., Smith, A.G., and Smith, D.G., 1990. A Geologic Time Scale 1989: Cambridge (Cambridge Univ. Press),

Harrison, C.G.A., 1980. Secular variation and excursions of the earth's magnetic field. J. Geophys. Res., 85:3511-3522.

Kirschvink, J.L., 1980. The least-squares line and plane and the analysis of palaeomagnetic data. Geophys. J. R. Astron. Soc., 62:699-718.

Larson, R.L., and Sager, W.W., 1992. Skewness of magnetic anomalies M0 to M29 in the northwestern Pacific. In Larson, R.L., Lancelot, Y., et al., Proc. ODP, Sci. Results, 129: College Station, TX (Ocean Drilling Program), $471-481$.

Larson, R.L., Steiner, M.B., Erba, E., and Lancelot, Y., 1992. Paleolatitudes and tectonic reconstructions of the oldest portion of the Pacific Plate: a comparative study. In Larson, R.L., Lancelot, Y., et al., Proc. ODP, Sci. Results, 129: College Station, TX (Ocean Drilling Program), 615-631.

McFadden, P.L., and Reid, A.B., 1982. Analysis of paleomagnetic inclination data. Geophys. J. R. Astron. Soc., 69:307-319.

Sager, W.W., 1992. Seamount age estimates from paleomagnetism and their implications for the history of volcanism on the Pacific Plate. In Keating, B.H., and Bolton, B. (Eds.), Geology and Offshore Mineral Resources of the Central Pacific Basin. Circum.-Pac. Counc. Energy Miner. Resour., Earth Sci. Ser., 14:21-37.

Sager, W.W., and Pringle, M.S., 1988. Mid-Cretaceous to Early Tertiary apparent polar wander path of the Pacific Plate. J. Geophys. Res., 93:11753-11771.

Sager, W.W., Winterer, E.L., Firth, J.V., et al., 1993. Proc. ODP, Init. Repts., 143: College Station, TX (Ocean Drilling Program).

Steiner, M.B., 1983. Geomagnetic excursion in the late Cretaceous. Geophys. J. R. Astron. Soc., 73:17-25.

Steiner, M.B., and Wallick, B.P., 1992. Jurassic to Paleogene Paleolatitudes of the Pacific Plate derived from the paleomagnetism of the sedimentary sequences at Sites 800,801 , and 802 . In Larson, R.L., Lancelot, Y., et al., Proc. ODP, Sci. Results, 129: College Station, TX (Ocean Drilling Program), 431-446.

Tarduno, J.A., 1990. Absolute inclination values from deep sea sediments: a reexamination of the Cretaceous Pacific record. Geophys. Res. Lett., 17:101-104.

Winterer, E.L., Natland, J.H., van Waasbergen, R.J., Duncan, R.A., McNutt, M.K., Wolfe, C.J., Premoli Silva, I., Sager, W.W., and Sliter, W.V., 1993. Cretaceous guyots in the Northwest Pacific: an overview of their geology and geophysics. In Pringle, M.S., Sager, W.W., Sliter, W.V., and Stein, S. (Eds.), The Mesozoic Pacific: Geology, Tectonics, and Volcanism. Am. Geophys. Union, Geophys. Monogr., 77:307-334.

Abbreviations for names of organizations and publications in ODP reference lists follow
the style given in Chemical Abstracts Service Source Index (published by American Chemical Society).

Date of initial receipt: 29 November 1993

Date of acceptance: 21 April 1994

Ms 143SR-250 